\title{
Penisporolides A and B, Two New Spiral Lactones from the Marine-derived Fungus Penicillium sp.
}

\author{
Xiang Li, Isabel Sattler, Wenhan Lin
}

Received: November 4, 2006 / Accepted: February 17, 2007

(C) Japan Antibiotics Research Association

\begin{abstract}
In our continued screening on bioactive constituents from marine-derived fungi, two novel compounds containing a rare spiral-lactone skeleton were isolated from lyophilized culture broth of the marinederived fungus Penicillium sp. The structures of penisporolides $\mathrm{A}$ and $\mathrm{B}$ were elucidated on the basis of extensive 1D and 2D NMR as well as HRESI-MS spectroscopic data analysis. The relative stereochemistries of the compounds were assessed by analysis of NOESY data together with the comparison with data from previous literatures.
\end{abstract}

Keywords penisporolide A, penisporolide B, marinederived fungus, Penicillium sp.

\section{Introduction}

Antimicrobial and cytotoxic activities [1, 2] were discovered from Penicillium sp. (HKI Strain No. GT2002605), an organism that was purified from the mangrove plant Kandelia candel. From lyophilized culture broth of this fungus, we discovered two novel compounds containing a rare spiral-lactone skeleton, namely penisporolides A (1) and B (2). The structures of the compounds were elucidated on the basis of $\mathrm{MS},{ }^{1} \mathrm{H}$ and ${ }^{13} \mathrm{C}$ NMR, including 2D NMR spectroscopic analysis. This paper describes the structure elucidation of the obtained compounds.

X. Li (Corresponding author), W. Lin: State Key Laboratory of Natural and Biomimetic Drugs, Peking University, Beijing 100083, P.R. China, E-mail: lixi@agr.gc.ca

X. Li, I. Sattler: Hans-Knöll-Institute for Natural Products Research, Beutenbergstraße 11, D-07745, Jena, Germany

\section{Results and Discussion}

Continuing the chemical study of marine-derived fungi, we isolated and characterized two new lactones $\mathbf{1}$ and $\mathbf{2}$ from the methanol extract of marine-derived fungus Penicillium sp.

The first compound isolated was a pale yellow oil with the molecular formula $\mathrm{C}_{18} \mathrm{H}_{30} \mathrm{O}_{5}$, as deduced from HRESIMS $m / z: 349.2033[\mathrm{M}+\mathrm{Na}]^{+}$(calcd 349.1991$)$ and ${ }^{13} \mathrm{C}$ NMR spectroscopic data, requiring four sites of unsaturation. The IR spectrum of $\mathbf{1}$ showed bands characteristic of lactone carbonyl $\left(v_{\max }=1774 \mathrm{~cm}^{-1}\right)$ functionality. The ${ }^{13} \mathrm{C}$ NMR spectrum comprised eighteen carbon signals with the following multiplicities (DEPT spectrum): three quaternary carbons at $\delta 180.8$ (C-1), 44.4 $(\mathrm{C}-2)$ and 115.5 (C-6), four oxymethine carbons at $\delta 85.2$ (C-3), 80.5 (C-4), 78.8 (C-9) and 71.5 (C-16), eight methylene carbons at $\delta 42.4$ (C-5), 35.5 (C-7), 30.1 (C-8), 30.0 (C-12), 25.6 (C-13), 18.8 (C-14), 37.8 (C-15) and 39.7 (C-17), three methyl carbons at $\delta 23.1$ (C-10), 18.1 (C-11) and 9.8 (C-18). Comprehensive analysis of 2D NMR data, including the results of ${ }^{1} \mathrm{H}-{ }^{1} \mathrm{H}$ COSY, HMQC, and HMBC experiments have been used to elucidate the planar structure of 1 .

Analysis of the ${ }^{1} \mathrm{H}-{ }^{1} \mathrm{H}$ COSY (Fig. 1) and HMQC spectra suggested the presence of three ${ }^{1} \mathrm{H}-{ }^{1} \mathrm{H}$ spin systems: $\mathrm{H}_{3}-\mathrm{H}_{4}{ }^{-}$ $\mathrm{H}_{5}, \mathrm{H}_{7}-\mathrm{H}_{8}-\mathrm{H}_{9}, \mathrm{H}_{12}-\mathrm{H}_{13}-\mathrm{H}_{14}-\mathrm{H}_{15}-\mathrm{H}_{16}-\mathrm{H}_{17}-\mathrm{H}-{ }_{18}$. The longrang ${ }^{1} \mathrm{H}-{ }^{13} \mathrm{C}$ correlations were observed by $\mathrm{HMBC}$ spectrum (Fig. 1 and Table 1) as following: from $\mathrm{C}-1$ to $\mathrm{H}-$ 3, H-4, H-10, H-11; from C-2 to H-4, H-10, H-11; from C3 to H-4, H-5a, H-10, H-11; from C-5 to H-4, H-7; from C6 to H-3, H-4, H-5, H-7, H-8, H-9; from C-7 to H-5, H-9; from $\mathrm{C}-8$ to $\mathrm{H}-5, \mathrm{H}-9, \mathrm{H}-12$; from $\mathrm{C}-9$ to $\mathrm{H}-7, \mathrm{H}-13$. The skeleton of the compound was established by comparison the spectral data with those of cephalosporolide E, F and 
ascospiroketal A, B [5 7]. ${ }^{13} \mathrm{C}$ NMR data of $\mathbf{1}$ with those of former reported compounds showed very similar chemical shifts of C-1, C-4, C-5, C-6, C-7, C-8 and C-9. The carbon signals of C-2 and C-3 shifted upfield to $\delta 44.4$ and 85.2 , respectively, due to the dimethylation of 2 position. The side chain of 1 was determined by ${ }^{1} \mathrm{H}-{ }^{1} \mathrm{H}$ COSY (Fig. 1) together with HMQC spectral data analysis. All these data above led us to determine the planar structure of $\mathbf{1}$ as a spiral lactone substituted with long side

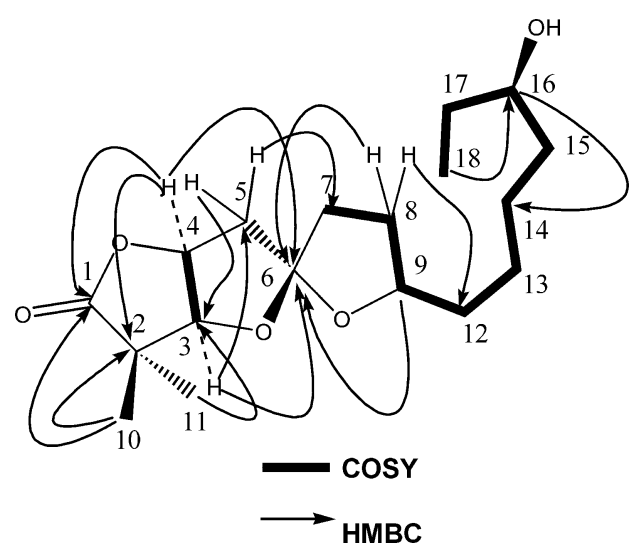

Fig. 1 Main COSY and HMBC correlations of penisporolide $\mathrm{A}(\mathbf{1})$. chain in 9-position.

The relative stereochemistry of $\mathbf{1}$ was assessed by analysis of NOESY data (Fig. 2) together with the comparison of literatures [7]. The NOESY spectrum showed the correlation between $\mathrm{H}-3(\delta 4.26)$ and $\mathrm{H}-11$ ( $\delta$ $1.24)$ indicated $\mathrm{C}-3$ had the $\beta$-orientation; H-3 showed correlation with H-4 $(\delta 5.01)$ indicated C-4 also had the $\beta$ orientation; $\mathrm{H}-5 \mathrm{~b}(\delta$ 2.52) showed cross-peak with $\mathrm{H}-7$ ( $\delta$ 2.10) and $\mathrm{H}-3$. The similarity of the ${ }^{1} \mathrm{H}$ and ${ }^{13} \mathrm{C}$ NMR spectra of 1 when compared to those of ascospiroketal A [7] indicated that the former natural product possessed the same configuration, but differed in their substituents. This was confirmed by optical rotation comparison with the known compound. 1 possessed optical rotation as $[\alpha]_{\mathrm{D}}^{20}$ $+37(c 0.5$ in $\mathrm{MeOH})$ similar with that of ascospiroketal A $\left([\alpha]_{\mathrm{D}}^{23}+20(c 0.45\right.$ in $\mathrm{MeOH})$. Thus, we can establish the relative configuration of $\mathbf{1}$ as showed in Fig. 2.

2 was obtained as pale yellow oil, and its molecular formula was established to be $\mathrm{C}_{17} \mathrm{H}_{26} \mathrm{O}_{5}$ from HRESI-MS $m / z: 333.1682[\mathrm{M}+\mathrm{Na}]^{+}$(calcd 333.1678). The similarity of the ${ }^{1} \mathrm{H}$ and ${ }^{13} \mathrm{C}$ NMR spectra of 2 (Table 2) when compared to those of $\mathbf{1}$ (Table 1) indicated that they possessed the same skeleton, but differed in their side chain substituents. The ${ }^{13} \mathrm{C}$ NMR spectra of $\mathbf{2}$ (Table 2) appeared an additional carbonyl group resonating at $\delta 212.5$ (s)

Table $1{ }^{1} \mathrm{H}$ and ${ }^{13} \mathrm{C}$ NMR spectral data of penisporolide $\mathrm{A}$ in $\mathrm{CDCl}_{3}{ }^{\mathrm{a}}$

\begin{tabular}{|c|c|c|c|c|c|}
\hline$\#$ & ${ }^{1} \mathrm{H}$ NMR & ${ }^{13} \mathrm{C}$ NMR & ${ }^{1} \mathrm{H}-{ }^{1} \mathrm{H} \operatorname{COSY}$ & HMBC & NOESY \\
\hline 1 & - & 180.8 (s) & - & - & - \\
\hline 2 & - & 44.4 (s) & - & - & - \\
\hline 3 & $4.26(d, J=3.6)$ & $85.2(d)$ & $\mathrm{H}-4$ & C-1, C-10, C-11, C-5, C-6 & $\mathrm{H}-4, \mathrm{H}-5, \mathrm{H}-10$ \\
\hline 4 & $5.01(\mathrm{~m})$ & $80.5(d)$ & $\mathrm{H}-3, \mathrm{H}-5$ & $\mathrm{C}-1, \mathrm{C}-2, \mathrm{C}-3, \mathrm{C}-5, \mathrm{C}-6$ & $\mathrm{H}-3$ \\
\hline $5 a$ & $2.35(d, J=3.6)$ & $42.4(t)$ & $\mathrm{H}-5 \mathrm{~b}, \mathrm{H}-4$ & C-3, C-6 , C-7, C-8 & - \\
\hline $5 b$ & $2.52(d, J=5.4)$ & & $\mathrm{H}-5 \mathrm{a}$ & C-6, C-7, C-8 & $\mathrm{H}-7, \mathrm{H}-3$ \\
\hline 6 & - & 115.5 (s) & - & - & - \\
\hline 7 & $2.10(\mathrm{~m})$ & $35.5(t)$ & $\mathrm{H}-8 \mathrm{a}, \mathrm{H}-8 \mathrm{~b}$ & $C-5, C-6, C-9$ & $\mathrm{H}-5 \mathrm{~b}$ \\
\hline $8 a$ & $2.15(\mathrm{~m})$ & $30.1(t)$ & $\mathrm{H}-7, \mathrm{H}-8 \mathrm{~b}, \mathrm{H}-9$ & $C-6, C-12$ & $\mathrm{H}-9$ \\
\hline $8 b$ & $2.20(\mathrm{~m})$ & & $\mathrm{H}-7, \mathrm{H}-8 \mathrm{a}$ & $\mathrm{C}-6, \mathrm{C}-12$ & - \\
\hline 9 & $4.05(\mathrm{~m})$ & $78.8(d)$ & $\mathrm{H}-8 \mathrm{a}, \mathrm{H}-12$ & C-6, C-7, C-8, C-13 & $\mathrm{H}-8 \mathrm{a}$ \\
\hline 10 & 1.19 (s) & $23.1(q)$ & - & C-1, C-2, C-3, C-11 & $\mathrm{H}-3$ \\
\hline 11 & $1.24(\mathrm{~s})$ & $18.1(q)$ & - & $C-1, C-2, C-3, C-10$ & - \\
\hline 12 & $1.55(\mathrm{~m})$ & $30.0(t)$ & $\mathrm{H}-9, \mathrm{H}-13$ & C-8, C-14 & - \\
\hline 13 & $1.50(\mathrm{~m})$ & $25.6(t)$ & $\mathrm{H}-12, \mathrm{H}-14$ & $C-9, C-12, C-15$ & - \\
\hline 14 & $1.53(\mathrm{~m})$ & $18.8(t)$ & $\mathrm{H}-13, \mathrm{H}-15$ & C-12, C-16 & - \\
\hline 15 & $1.50(\mathrm{~m})$ & $37.8(t)$ & $\mathrm{H}-14, \mathrm{H}-16$ & C-13, C-16, C-17 & - \\
\hline 16 & $3.50(\mathrm{~m})$ & $71.5(d)$ & $\mathrm{H}-15, \mathrm{H}-17$ & C-14, C-18 & - \\
\hline 17 & $1.50(\mathrm{~m})$ & $39.7(t)$ & $\mathrm{H}-16, \mathrm{H}-18$ & C-15 & - \\
\hline 18 & $0.90(t, J=4.0)$ & $9.8(q)$ & $\mathrm{H}-17$ & C-16, C-17 & - \\
\hline
\end{tabular}

\footnotetext{
${ }^{a}$ Chemical shift $\delta$ and (multiplicity, $J$ in $\mathrm{Hz}$ ). — No signal appeared in spectra.
} 
which showed HMBC correlation to $\delta 2.43(2 \mathrm{H}, \mathrm{t}, J=4.2$, $\mathrm{H}-13)$ and $2.46(2 \mathrm{H}, \mathrm{t}, J=4.2, \mathrm{H}-15)$ indicated that $\mathrm{C}-14$ had been substituted with ketone group. This observation together with NMR data comparison with $\mathbf{1}$ led us to establish the structure of $\mathbf{2}$. Compounds $\mathbf{1}$ and $\mathbf{2}$ showed no effects on xanthine oxidase, other bioactivities are under investigation.

\section{Experimental}

\section{General}

${ }^{1} \mathrm{H}$ and ${ }^{13} \mathrm{C}$ NMR spectra were measured on a Bruker Avance DRX 500 spectrometer using TMS as an internal standard. Chemical shifts $(\delta)$ expressed in parts per million $(\mathrm{ppm})$ and coupling constants $(J)$ are reported in Hertz $(\mathrm{Hz})$. ESI-MS spectra were recorded on a triple quadrupole

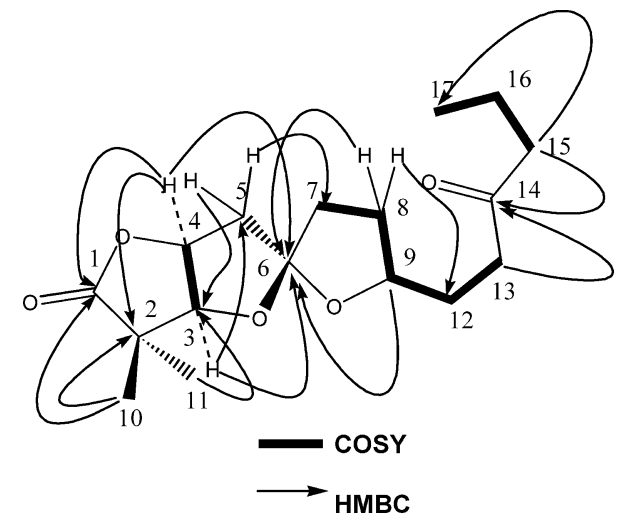

Fig. 3 Main COSY and HMBC correlations of penisporolide B (2).

Fig. 2 Key NOESY correlations of $\mathbf{1}$.

Table $2{ }^{1} \mathrm{H}$ and ${ }^{13} \mathrm{C}$ NMR spectral data of penisporolide $\mathrm{B}$ in $\mathrm{CDCl}_{3}{ }^{\mathrm{a}}$

\begin{tabular}{|c|c|c|c|c|c|}
\hline \# & ${ }^{1} \mathrm{H} N M R$ & ${ }^{13} \mathrm{C}$ NMR & ${ }^{1} \mathrm{H}-{ }^{1} \mathrm{H}$ COSY & $\mathrm{HMBC}$ & NOESY \\
\hline 1 & - & 180.5 (ND) & - & - & - \\
\hline 2 & - & 44.7 (s) & - & - & - \\
\hline 3 & $4.30(d, J=3.6)$ & $85.2(d)$ & $\mathrm{H}-4$ & C-1, C-10, C-11, C-5, C-6 & $\mathrm{H}-4, \mathrm{H}-5, \mathrm{H}-10$ \\
\hline 4 & $5.05(\mathrm{td}, J=5.4,3.6)$ & 80.5 (d) & $\mathrm{H}-3, \mathrm{H}-5$ & $C-1, C-3, C-5, C-6$ & $\mathrm{H}-3$ \\
\hline $5 a$ & $2.33(d, J=3.6)$ & $42.5(t)$ & $\mathrm{H}-5 \mathrm{~b}, \mathrm{H}-4$ & $\mathrm{C}-3, \mathrm{C}-6, \mathrm{C}-7, \mathrm{C}-8$ & $\mathrm{H}-3$ \\
\hline $5 b$ & $2.50(d, J=5.4)$ & & $\mathrm{H}-5 \mathrm{a}$ & $\mathrm{C}-6, \mathrm{C}-7, \mathrm{C}-8$ & $\mathrm{H}-7$ \\
\hline 6 & - & 115.5 (ND) & - & - & - \\
\hline 7 & $2.09(\mathrm{~m})$ & $35.5(t)$ & $\mathrm{H}-8 \mathrm{a}, \mathrm{H}-8 \mathrm{~b}$ & $C-5, C-6, C-9$ & $H-5 b$ \\
\hline $8 a$ & $2.16 \sim 2.18(\mathrm{~m})$ & $30.0(t)$ & $\mathrm{H}-7, \mathrm{H}-8 \mathrm{~b}, \mathrm{H}-9$ & $\mathrm{C}-6, \mathrm{C}-12$ & $\mathrm{H}-9$ \\
\hline $8 b$ & $2.16 \sim 2.18(\mathrm{~m})$ & - & $\mathrm{H}-7, \mathrm{H}-8 \mathrm{a}$ & $\mathrm{C}-6, \mathrm{C}-12$ & - \\
\hline 9 & $4.05(t, J=3.6)$ & $78.5(d)$ & $\mathrm{H}-8 \mathrm{a}, \mathrm{H}-12$ & C-7, C-8, C-13 & $\mathrm{H}-8 \mathrm{a}$ \\
\hline 10 & 1.23 (s) & $23.1(q)$ & - & C-1, C-3, C-11 & $\mathrm{H}-3$ \\
\hline 11 & 1.29 (s) & $18.1(q)$ & - & C-1, C-3, C-10 & - \\
\hline 12 & $1.50(\mathrm{~m})$ & $20.1(t)$ & $\mathrm{H}-9, \mathrm{H}-13$ & C-8, C-14 & - \\
\hline 13 & $2.43(\mathrm{t}, J=4.2)$ & $34.9(\mathrm{t})$ & $\mathrm{H}-12$ & C-12, C-14 & - \\
\hline 14 & - & 212.5 (ND) & - & - & - \\
\hline 15 & $2.46(t, J=4.2)$ & $42.3(\mathrm{t})$ & $\mathrm{H}-16$ & C-14, C-17 & - \\
\hline 16 & $1.27(\mathrm{~m})$ & $17.3(t)$ & $\mathrm{H}-15, \mathrm{H}-17$ & $C-14, C-17$ & - \\
\hline 17 & $0.95(t, J=6.9)$ & 13.7 (q) & $\mathrm{H}-16$ & $C-15$ & - \\
\hline
\end{tabular}

${ }^{a}$ Chemical shift $\delta$ and (multiplicity, $J$ in $\mathrm{Hz}$ ). ND, The signal was not detected in survey spectra, but was apparent in HMBC spectra.

- No signal appeared in spectra. 
mass spectrometer Quattro (VG Biotech, Altrincham, England) and HRESI-MS spectra were obtained on a Bruker FT-ICRMS spectrometer. Column chromatography was carried out with Silica gel (Merck GMBH Germany, 200 300 mesh), Lichrospher RP-8 (20 $\mu \mathrm{m})$, TLC: silica gel plates (Macherey-Nagel, SilG/UV254, $0.20 \mathrm{~mm}$ ), spots were detect by $\mathrm{UV}_{254}$ and anisaldehyde $/ \mathrm{H}_{2} \mathrm{SO}_{4}(10 \%)$; Sephadex LH-20 (Pharmacia); Fermentation: 200 liters fermenter (Braun Diessel).

\section{Penicillium Strain}

The strain (HKI strain GT2002605) was purified from mangrove plant Kandelia candel that was collected from Hainan Island, Southern China, in October 2002. The species was identified by Prof. Peng Lin from Xiamen University. The strain was stored in Hans-Knöll-Institute of Natural Products Research Jena, Germany. The strain was cultured at $21^{\circ} \mathrm{C}$ in 300 liter fermenter with control of $\mathrm{pH}$ as 5.5 for 7 days.

\section{Culture Conditions}

The spores of strain growing on agar slants (artificial sea salt solution $800 \mathrm{ml} / \mathrm{liter}$, nalidixic acid $20 \mathrm{mg} /$ liter and cycloheximide $30 \mathrm{mg} / \mathrm{liter}$ ) was transferred to a flask $(20 \mathrm{ml})$ and was inoculated on liquid medium (glucose $5 \mathrm{~g} /$ liter, peptone $1 \mathrm{~g} /$ liter, yeast extract $0.5 \mathrm{~g} /$ liter, beef extract $0.5 \mathrm{~g} /$ liter, $\mathrm{NaCl} 3 \mathrm{~g} /$ liter). The flask was incubated at $28^{\circ} \mathrm{C}$ on a rotary shaker for 48 hours, and the mycelium was transferred to a 1-liter Erlenmeyer flask containing culture liquid $(400 \mathrm{ml})$. After 48 hours, the mycelium was transferred to 200 liter fermenter then incubated at $28^{\circ} \mathrm{C}$ with $\mathrm{pH}$ controlled at 5.5 for 7 days.

\section{Extraction and Isolation}

The lyophilized culture broth was extracted with $\mathrm{MeOH}$ at room temperature. The extract was concentrated under reduced pressure to give the dark brown oily residue $(27 \mathrm{~g})$ that was fractionated by reverse phase (C-8) using $\mathrm{H}_{2} \mathrm{O}$, aqueous $\mathrm{MeOH}(30 \%, 60 \%, 90 \%)$ and $\mathrm{MeOH}$ to give four fractions: the $90 \% \mathrm{MeOH}$ fraction was further fractionated on a Silica gel column ( $n$-hexane : EtOAc $=20: 1,5: 1$, $1: 1)$ to get four fractions, the third part of fraction one was separated by column chromatography with Sephadex LH$20\left(\mathrm{CHCl}_{3}: \mathrm{MeOH}=1: 1\right)$ to purify $1(86 \mathrm{mg}$, yield: $\left.3.0 \times 10^{-3}\right)$ and $2\left(4.2 \mathrm{mg}\right.$, yield: $\left.0.15 \times 10^{-3}\right)$.

Penisporolide A (1)

1 was obtained as a pale yellow oil; $[\alpha]_{\mathrm{D}}^{20}+37$ (c 0.5 in $\mathrm{MeOH})$. UV $\lambda_{\max }(\mathrm{MeOH}) \mathrm{nm}: 202,224$ (sh). IR $v_{\max }^{\mathrm{KBr}}$ $\mathrm{cm}^{-1}: 2951,2936,1774$. ESI-MS [+]: $m / z=675.36$ [2M+ $\mathrm{Na}]^{+}, 349.22[\mathrm{M}+\mathrm{Na}]^{+}, 327.22[\mathrm{M}+\mathrm{H}]^{+}$; HRESI-MS $m / z$ :
$349.2033[\mathrm{M}+\mathrm{Na}]^{+}$(calcd for $\left.\mathrm{C}_{18} \mathrm{H}_{30} \mathrm{O}_{5} \mathrm{Na}, 349.1991\right) ;{ }^{1} \mathrm{H}$ and ${ }^{13} \mathrm{C}$ NMR data see Table 1.

Penisporolide B (2)

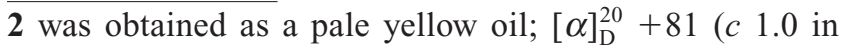
$\mathrm{MeOH})$. IR $v_{\max }^{\mathrm{KBr}} \mathrm{cm}^{-1}: 2957,2935,1765,1743$. ESI-MS [+]: $m / z=311.77[\mathrm{M}+\mathrm{H}]^{+}$; HRESI-MS $m / z: 333.1682$ $[\mathrm{M}+\mathrm{Na}]^{+}$(calcd for $\mathrm{C}_{17} \mathrm{H}_{26} \mathrm{O}_{5} \mathrm{Na}, 333.1678$ ). ${ }^{1} \mathrm{H}$ and ${ }^{13} \mathrm{C}$ NMR data see Table 2.

\section{Assay for Inhibition of XOD Activity}

Xanthine oxidase activity was evaluated by the spectrophotometric measurement of the formation of uric acid from xanthine [8]. A $100 \mu \mathrm{M}$ solution of xanthine in $0.1 \mathrm{M}$ phosphate buffer $\mathrm{pH} 7.8$ with 0.05 units $/ \mathrm{ml}$ of xanthine oxidase was incubated for 15 minutes at room temperature and read at $295 \mathrm{~nm}$ against a control sample, which did not contain the enzyme. Five gradient concentrations of compound $\mathbf{1}$ and $\mathbf{2}(10,50,100,200$, $400 \mu \mathrm{g} / \mathrm{ml}$ ) were added to samples before the enzyme had been added, and their effect on the generation of uric acid was used to calculate the $\mathrm{IC}_{50}$ value.

Acknowledgments We are grateful to Dr. F. Gollmick (HKI) and Professor Zhiwei Deng (Beijing Normal University) for acquiring the NMR spectra. This project is part of a collaboration between the Hans-Knöll-Institute for Natural Product Research (HKI) and the National Research Laboratory of Natural and Biomimetic Drugs, Peking University (Beijing) and was funded by the Germany Federal Ministry for Education and Research and Technology (BMBF 0312849A, CHN02/323 and CHN 02/322).

\section{References}

1. Blunt JW, Copp BR, Munro MHG. Marine natural products. Nat Prod Rep 22: 1-61 (2005)

2. Grabley S, Thiericke R. In Drug Discovery from Nature. Springer Verlag, Berlin, pp. 124-125 (1999)

3. Afghan F, John G, James R, Jacqueline AT. Two $\mathrm{C}_{10}$ lactones from Cephalosporium Aphidicola. Phytochemistry 38: 557-558 (1995)

4. Vatcharin R, Songyos P, Chaveng P, Masahiko I, Sumilee S. 10 -Membered macrolides from the insect pathogenic fungus Cordyceps militaris BCC 2816. J Nat Prod 67: 1953-1955 (2004)

5. Ackland MJ, Hanson JR, Hitchcock PB, Mabelis RP, Ratcliffe AH. The structure of thiobiscephalosporolide A, a dimeric pentaketide macrolide from Cephalosporium aphidicola. J Chem Soc Perkin Trans I 5: 2755-2757 (1984)

6. Ackland MJ, Hanson JR, Hitchcock PB, Ratcliffe AH. Structures of the cephalosporolides $B \sim F$, a group of $C_{10}$ 
lactones from Cephalosporium aphidicola. J Chem Soc Perkin Trans I 2: 843-847 (1985)

7. Seibert SF, Krick A, Eguereva E, Kehraus S, Konig GM. Ascospiroketals A and B, unprecedented cycloethers from the marine-derived fungus Ascochyta salicorniae. Organic Lett 9: 239-242 (2007)

8. Robak J, Gryglewsky RJ. Flavonoids are scavengers of superoxide anions. Biochem J 37: 837-841 (1988) 